\title{
Expression of regulatory receptors on $\gamma \delta$ T Cells and their cytokine production in Behcet's disease
}

\author{
Gunes Parlakgul ${ }^{1 \dagger}$, Ekin Guney ${ }^{1 \dagger}$, Burak Erer $^{2}$, Zeki Kilıcaslan ${ }^{3}$, Haner Direskeneli ${ }^{4}$, Ahmet Gul $^{2}$ and \\ Guher Saruhan-Direskeneli ${ }^{5^{*}}$
}

\begin{abstract}
Introduction: Behcet's disease (BD) is a multi-systemic disorder with muco-cutaneous, ocular, arthritic, vascular or central nervous system involvement. The role of $\gamma \delta$ T cells is implicated in BD. The activation status of $\gamma \delta$ T cells and their cytokine secretion against phosphoantigens are evaluated in BD.
\end{abstract}

Methods: NKG2A, NKG2C, NKG2D, CD16 and CCR7 molecules on $\gamma \delta$ T cells were analyzed in 70 BD, 27 tuberculosis (TB) patients and 26 healthy controls (HC). Peripheral $\gamma \delta T$ cells were expanded with a phosphoantigen (BrHPP) and IL-2, restimulated with BrHPP and a TLR3 ligand, and cytokine production was measured.

Results: $\gamma \delta$ T cells were not increased in both $\mathrm{BD}$ and TB patients, but the proportions of TCRV $\delta 2^{+} \mathrm{T}$ cells were lower (58.9 and 50.7 vs. $71.7 \%, P=0.04$ and $P=0.005$ ) compared to HC. Higher proportion of TCRV $\delta 2^{+} \mathrm{T}$ cells were CD16 ${ }^{+}$ (26.2 and 33.9 vs. $16.6 \%, P=0.02$ and $P=0.001$ ) and $C C R 7^{-}$( 32.2 and 27.9 vs. $17.7 \%, P<0.0001$ and $P=0.014$ ) in $B D$ and TB patients compared to HC. NKG2C $\gamma \delta^{+}$T cells were relatively increased ( 0.5 and 0.6 vs. $0.3 \%, P=0.008$ and 0.018 ), whereas NKG2D positivity was decreased in patients with $\mathrm{BD}$ and TB (77.7 and $75.8 \mathrm{vs.} 87.5 \%, P=0.001$ and 0.004$)$. Expansion capacity of $\gamma \delta$ T cells in BD and TB as well as production of IL-13, IFN- $\gamma$, granulocyte monocyte colony stimulating factor (GM-CSF), TNF- $\alpha, C C L 4$ and CCL5 in BD was lower compared to HC, when restimulated by TLR3 ligand and BrHPP.

Conclusion: The changes on $\gamma \delta$ T cells of BD as well as TB patients implicate that $\gamma \delta$ T cells have already been exposed to regulatory effects, which changed their activity. Lower cytokine response of $\gamma \delta T$ cells implicates down modulation of these cells in BD.

\section{Introduction}

Behcet's disease (BD) is a systemic inflammatory disorder with a diverse spectrum of clinical manifestations including mucocutaneous, ocular, vascular, gastro-intestinal, musculoskeletal and central nervous system involvements. A complex genetic background leading to a pro-inflammatory, innate immune system derived activation perpetuated by adaptive immune responses against environmental or auto-antigens is considered as the pathogenic mechanism in $\mathrm{BD}$ [1-3].

$\gamma \delta \mathrm{T}$ cells represent a minor $\mathrm{T}$ cell population (1 to $10 \%$ of peripheral blood (PB) T cells) with combining properties of adaptive and innate immunity that express $\mathrm{T}$ cell

\footnotetext{
* Correspondence: gsaruhan@istanbul.edu.tr

† Contributed equally

${ }^{5}$ Department of Physiology, Istanbul Medical Faculty, Istanbul University,

Millet Caddesi, Çapa, Istanbul, 34093 Turkey

Full list of author information is available at the end of the article
}

receptors (TCRs) comprised of $\gamma$ and $\delta$ heterodimer. TCRV $\gamma 9 \mathrm{~V} \delta 2^{+} \mathrm{T}$ cells, the major subset of $\gamma \delta \mathrm{T}$ cells $(70$ to 95\%) in the PB in humans, recognize non-peptidic phosphoantigens produced by microbial and eukaryotic mevalonate pathways in a TCR-dependent manner [4]. In adults with negative purified protein derivative (PPD) response, $\mathrm{TCRV} \gamma 9 \mathrm{~V} \delta 2^{+} \mathrm{T}$ cells reacting to isopentenyl pyrophosphate (IPP) secrete Th1 type cytokines (IFN- $\gamma$, TNF- $\alpha$ ) and MIP- $1 \beta$ (CCL4) [5]. TCRV $\gamma 9 \mathrm{~V} \delta 2^{+} \mathrm{T}$ cells stimulated in the presence of growth factors and cytokines can produce abundant amounts of the pro-inflammatory cytokines and change their phenotype from memory cells expressing $\mathrm{CCR}^{+}$to $\mathrm{CCR}^{+}$expressing cells [6].

The low affinity immunoglobulin receptor (Fc $\gamma$ RIII) CD16 is also shown to discriminate between two subsets of TCRV $\gamma 9 \mathrm{~V} \delta 2^{+} \mathrm{T}$ cells with distinct functional responses [7]. The expression of CD16 regulated cytolytic activity 
and production of inflammatory cytokines of the $\gamma \delta \mathrm{T}$ cells.

$\gamma \delta$ T cells also express inhibitory and activating members of the NK receptor family and modulate their effector functions, such as cytotoxicity and cytokine production. Among the NK receptors, heterodimeric "killer lectin receptors" of CD94 with NKG2A or NKG2C, exerting inhibitory or activating effects, respectively, interact with the nonclassical MHC class Ib molecule HLA-E [8]. The majority of TCRV $\gamma 9 \mathrm{~V} \delta 2^{+} \mathrm{T}$ cells harbor inhibitory receptors with CD94/NKG2A heterodimers and these cells exhibit a strong lytic activity [9].

Due to their small number in the peripheral blood, human $\gamma \delta$ T cells are often expanded before functional studies are performed. Short-term $\gamma \delta \mathrm{T}$ cells can be generated from PB by stimulating with $\gamma \delta$ T cell specific phosphoantigens and IL-2 in vitro. Depending on the stimulus and IL-2, purity of these cells may reach up to 70 to $95 \%$ [10]. As these expanded human $\gamma \delta \mathrm{T}$ cells are shown to express mRNA of TLR1-10 receptors similar to freshly isolated $\gamma \delta \mathrm{T}$ cells, costimulatory effects of TLR ligands could be demonstrated in vitro $[11,12]$.

Peripheral blood $\gamma \delta \mathrm{T}$ cells were elevated in BD, with a polyclonal activation [13,14]. $\gamma \delta \mathrm{T}$ cells were associated with active BD with higher expression of CD69 and production of IFN- $\gamma$ and TNF- $\alpha$ [15]. IPP-specific TCRV $\gamma 9 \mathrm{~V} \delta 2^{+}$Th1-like cells from intra-ocular fluid are generated from the eye of BD patients with uveitis [16]. In Italian BD patients, TCRV $\gamma 9 \delta 2^{+} \mathrm{T}$ lymphocytes were expanded and shown to express TNF receptor II and IL-12 receptor $\beta 1$ in active disease [17].

A more prominent pro-inflammatory cytokine secretion was shown from peripheral blood mononuclear cells (PBMCs) in BD patients in response to various antigens, including IPP and PPD, and increased IFN- $\gamma$ and IL-12 secretion was detected [18]. In this study, ex vivo PBMC are studied to evaluate $\gamma \delta \mathrm{T}$ cells as a candidate for an immune effector cell group in BD, in tuberculosis (TB) as an infectious disease control and in healthy controls (HC).

\section{Materials and methods Patients}

The patient group consisted of 70 patients with Behçet's disease (48 men and 22 women, mean age $36.8 \pm$ 11.0 years), followed at the BD Outpatient Clinic of the Division of Rheumatology, Istanbul Faculty of Medicine, Istanbul University. All patients met the International Study Group criteria for the classification of BD [19]. Active disease was defined as the presence of ongoing disease activity depending on the assessment of any exacerbation of characteristic BD symptoms within the last four weeks or at the first visit, including severe skin, mucosal and/or ocular manifestations that required
Table 1 Clinical features of 70 BD patients with active (A$B D$ ) and inactive disease (IA-BD)

\begin{tabular}{lcc}
\hline Clinical manifestations & $\begin{array}{c}\text { A-BD patients } \\
\text { N (\%) }\end{array}$ & $\begin{array}{c}\text { IA-BD patients } \\
\text { N (\%) }\end{array}$ \\
\hline Oral ulcer & 38 & 32 \\
Genital ulcer & $22(57.9)$ & $23(71.9)$ \\
Skin manifestations & $13(34.2)$ & $9(28.1)$ \\
Pathergy & $21(55.3)$ & $24(75)$ \\
Joint manifestations & $8(21.1)$ & $15(46.9)$ \\
Uveitis & $14(36.8)$ & $7(21.9)$ \\
Vascular manifestations & $6(15.8)$ & $4(12.5)$ \\
\hline
\end{tabular}

introduction or increase of systemic corticosteroids (Table 1 ). At the time of blood sampling, disease was active in 38 patients. Of the active patients, 36 were using colchicine, 24 of them were using immunosuppressant agents, such as azathioprine $(n=13)$ or corticosteroids $(n=19)$, and 2 patients were untreated. Seven inactive patients were using only colchicine and 25 patients were on colchicine as well as an immunosuppressant agent, such as azathioprine $(n=13)$ and low or medium dose corticosteroids $(n=14)$. Twenty-seven active TB patients (20 men and 7 women, mean age $37.0 \pm 15.7$ years) and 26 healthy volunteers (HC, 22 men and 4 women, mean age $38.1 \pm 9.5$ years) were enrolled as control groups. Ethics Committee of Istanbul Faculty of Medicine approved the study protocol, and all study donors provided written informed consent according to the Declaration of Helsinki prior to blood collection.

\section{Cell preparation - flow cytometry}

PBMCs were isolated from EDTA- anticoagulated venous blood by density-gradient centrifugation (Lymphoprep, Eurochrom, Berlin, Germany). Fluorescence-conjugated monoclonal antibodies $(\mathrm{mAb})$ and their target antigens used in the study were as follows: CD45/FITC (fluorescein isothiocyanate)-CD14/R-PE (R-phycoerythrin) (Ancell Corporation, Bayport, MN, USA), CD16/PC5 (antiFc $\gamma$ RIII, 368), CD56/PC5 (anti-NCAM, N901), pan- $\gamma \delta /$ FITC (Immu510), 82/FITC (Immu389), CD8/PC5 (B9.11), NKG2D/PE (ON72), NKG2A/PE (Z199, Beckman-Coulter, Immunotech, Marseille Cedex, France), CD94/FITC (70 kDa dimer, Kp43, HP-3D9, BD Biosciences, USA), NKG2C/PE (134591) and CCR7/PE (150503, R\&D Systems, USA). For every antibody combination, $1 \mu \mathrm{l}$ of antibody per $10^{5}$ PBMCs was incubated at $4^{\circ} \mathrm{C}$ for $20 \mathrm{~min}$ utes, washed and analyzed by flow cytometer (Epics XL, Beckman-Coulter, USA). Results are expressed as percentages of the respective positive cells in the lymphocyte gate.

\section{In vitro expansion of TCRV $\gamma 9 \mathrm{~V} \delta 2^{+} \mathrm{T}$ lymphocytes}

PBMCs were cultured in 96-well plates at a concentration of $10^{6}$ cells $/ \mathrm{ml}$ in RPMI 1640 supplemented with 
10\% fetal calf serum (Gibco, Life Technologies, USA), $2 \mathrm{mM}$ L-glutamine, $1 \%$ sodium pyruvate and $100 \mathrm{U} / \mathrm{ml}$ penicillin/streptomycin (Sigma, Deisenheim, Germany) at $37^{\circ} \mathrm{C}$ and $5 \% \mathrm{CO}_{2}$. The proportion of $\gamma \delta \mathrm{T}$ cells was measured on the first day. For the expansion of TCRV $\gamma 9 \mathrm{~V} \delta 2^{+}$ $\mathrm{T}$ cells, PBMCs were cultured in medium alone or in the presence of a synthetic analogue of natural phosphoantigens (bromohydrin pyrophosphate, BrHPP, $3 \mathrm{mM}$, kindly provided by Helene Sicard, Innate Pharma, Marseille, France). Responsive $\gamma \delta \mathrm{T}$ cells were expanded by adding $100 \mathrm{IU} / \mathrm{ml}$ recombinant human interleukin-2 (IL-2) on the second and fifth day of the cell culture. After eight days, cells were washed and expansion of TCRV $\gamma 9 \mathrm{~V} \delta 2^{+} \mathrm{T}$ cells was assessed by staining the cultured cells with antiTCRV82 (Immu389), as described above. Cultures of donors with at least $70 \% \gamma \delta^{+}\left(\mathrm{TCRV} \delta 2^{+}\right)$T cells (23 active $\mathrm{BD}, 20$ inactive BD, $9 \mathrm{~TB}, 20 \mathrm{HC}$ ) were restimulated with the $50 \mathrm{mg} / \mathrm{ml}$ Polyinosinic:polycytidylic acid (PolyI:C, TLR3 agonist), $3 \mathrm{mM} \mathrm{BrHPP}$ or PolyI:C and BrHPP at the eighth day. The levels of IL-13, interferon- $\gamma$ (IFN- $\gamma$ ), tumor necrosis factor- $\alpha$ (TNF- $\alpha$ ), granulocyte monocyte colony stimulating factor (GM-CSF), CCL4 (macrophage inflammatory protein $1-\beta$ ) and CCL5 (RANTES, Regulated on Activation, Normal T Expressed and Secreted) were measured in the supernatants after 24 hours of the restimulation by multiplex ELISA (Procarta, Luminex, Affymetrix, CA, USA).

\section{Statistical analysis}

The results are presented as mean and standard deviations throughout the manuscript. Cytokine levels were measured as "median intensity values", and the direct readings were evaluated instead of transformation to $\mathrm{pg} / \mathrm{ml}$. The parameters compared between patients and controls were subjected to the non-parametric Mann-Whitney U-test. The proportions of expanded $\gamma \delta \mathrm{T}$ cells were compared with the chi square test.

\section{Results}

Phenotype of $\boldsymbol{\gamma} \boldsymbol{\delta} \mathrm{T}$ lymphocytes in peripheral blood

The proportions of $\gamma \delta^{+}$T cells in PBMC were relatively low in BD patients and in both disease (TB) and healthy control (HC) groups (Table 2). Pan $\gamma \delta^{+}$T cells were slightly increased only in patients with inactive BD (IA-BD) compared to HC (Mean: 4.7 vs. $3.6 \%, P=0.029$ ). The difference of pan $\gamma \delta^{+} \mathrm{T}$ cells between active BD (A-BD) and IA-BD patients was not significant. The proportion of major $\gamma \delta \mathrm{T}$ cell population in the PB, namely TCRV $\gamma 9 \mathrm{~V} \delta 2$ ${ }^{+} \mathrm{T}$ cells (shown with anti-V $\delta 2$ antibody) was similar in all groups (Table 2). When compared among the pan $\gamma \delta^{+}$ $\mathrm{T}$ cells, the dominance of TCRV $\delta 2^{+} \mathrm{T}$ cells was less prominent in $\mathrm{BD}$ and particularly in the IA-BD group compared to $\mathrm{HC}$ (58.9 and 54 vs. $71.7 \%, P=0.04$ and $P=$ 0.014 , respectively). This significantly lower proportion of TCRV $\delta 2^{+}$of pan $\gamma \delta^{+} \mathrm{T}$ cells was observed in TB as well (50.7\%, compared to HC $P=0.005$ ).

To access the functional status of the $\gamma \delta$ T cells, surface expression of several co-stimulatory receptors was screened on these cells. The immunoglobulin receptor CD16, discriminating two subsets of TCRV $\gamma 9 \mathrm{~V} \delta 2^{+} \mathrm{T}$ cells with distinct functional responses, was evaluated as [7] an activation receptor for TCRV $\delta 2^{+} \mathrm{T}$ cells. CD16 expression on these cells was higher in both in $\mathrm{BD}$ patients (including active and inactive) compared to $\mathrm{HC}$ (26.2 vs. $16.6 \%, P=$ 0.02). This TCRV $\delta 2^{+} \mathrm{T}$ cell population expressing CD16 was even more increased in TB group compared to $\mathrm{HC}$ (33.9\%, $P=0.001$, Figure 1).

When pan $\gamma \delta^{+} \mathrm{T}$ cells are analyzed for expression of NKG2A or NKG2C receptors, the higher fraction of TCRV $\gamma 9 \mathrm{~V} \delta 2^{+} \mathrm{T}$ cells expressed inhibitory NKG2A rather than activating NKG2C in all groups as shown previously [9] (Table 2). Similar to a previous study [20], the fraction of $\mathrm{NKG} 2 \mathrm{C}^{+} \gamma \delta^{+} \mathrm{T}$ cells varied widely in all groups of this study. However, a slight increase of activating NKG2C ${ }^{+} \gamma \delta^{+} \mathrm{T}$ cells among the PB lymphocytes was observed in

Table 2 Phenotypic features of $\gamma \delta$ T cells in BD, TB patients and healthy controls (HC)

\begin{tabular}{|c|c|c|c|c|c|}
\hline Subtype & BD & TB & $\mathrm{HC}$ & BD vs. $\mathrm{HC}$ & TB vs. HC \\
\hline & 70 & 27 & 26 & & \\
\hline$\gamma \delta^{+} \mathrm{T}$ & $4.3 \pm 2.2$ & $3.5 \pm 2.6$ & $3.6 \pm 2.5$ & & \\
\hline $\mathrm{TCRV}_{\delta} 2^{+} \mathrm{T}$ & $2.6 \pm 1.9$ & $2.2 \pm 2.5$ & $2.4 \pm 2$ & & \\
\hline $\operatorname{TCRV} \delta 2^{+} \mathrm{T}$ of $\gamma \delta \mathrm{T}$ & $58.9 \pm 24.3$ & $50.7 \pm 23.8$ & $71.7 \pm 25.7$ & 0.04 & 0.005 \\
\hline $\mathrm{CD}_{16}{ }^{+}$of TCRV $\delta 2^{+} \mathrm{T}$ & $26.2 \pm 19.6$ & $33.9 \pm 19.1$ & $16.6 \pm 13$ & 0.02 & 0.001 \\
\hline $\mathrm{CCR7}^{-}$of TCRV $\delta 2^{+} \mathrm{T}$ & $32.2 \pm 18.5$ & $27.9 \pm 15.9$ & $17.7 \pm 9.2$ & $<0.001$ & 0.014 \\
\hline $\mathrm{NKG}_{2} \mathrm{~A}^{+} \gamma \boldsymbol{\delta}^{+} \mathrm{T}$ & $1.8 \pm 1.4$ & $1.3 \pm 1.6$ & $1.2 \pm 0.7$ & & \\
\hline $\mathrm{NKG}_{2} \mathrm{~A}^{+}$of $\gamma \delta^{+} \mathrm{T}$ & $38 \pm 20.9$ & $32.6 \pm 20.3$ & $39.4 \pm 15$ & & \\
\hline $\mathrm{NKG} \mathrm{C}^{+} \gamma \delta^{+} \mathrm{T}$ & $0.53 \pm 0.44$ & $0.64 \pm 0.8$ & $0.3 \pm 0.3$ & 0.008 & 0.018 \\
\hline $\mathrm{NKG} 2 \mathrm{C}^{+}$of $\gamma \delta \mathrm{T}$ & $13.5 \pm 11.8$ & $14.3 \pm 13.9$ & $11.3 \pm 9.3$ & & \\
\hline NKG2D ${ }^{+} \gamma \delta^{+} \mathrm{T}$ & $3.4 \pm 1.9$ & $2.7 \pm 2$ & $2.8 \pm 1.4$ & & \\
\hline $\mathrm{NKG}_{2 \mathrm{D}^{+}}$of $\gamma \delta \mathrm{T}$ & $77.7 \pm 15.3$ & $75.8 \pm 17.5$ & $87.5 \pm 11.5$ & 0.001 & 0.004 \\
\hline
\end{tabular}

Mean values \pm S.D. are presented. $P$-values of respective comparisons are listed in left columns. 


\section{TCRV $\delta 2^{+} T$ cells}

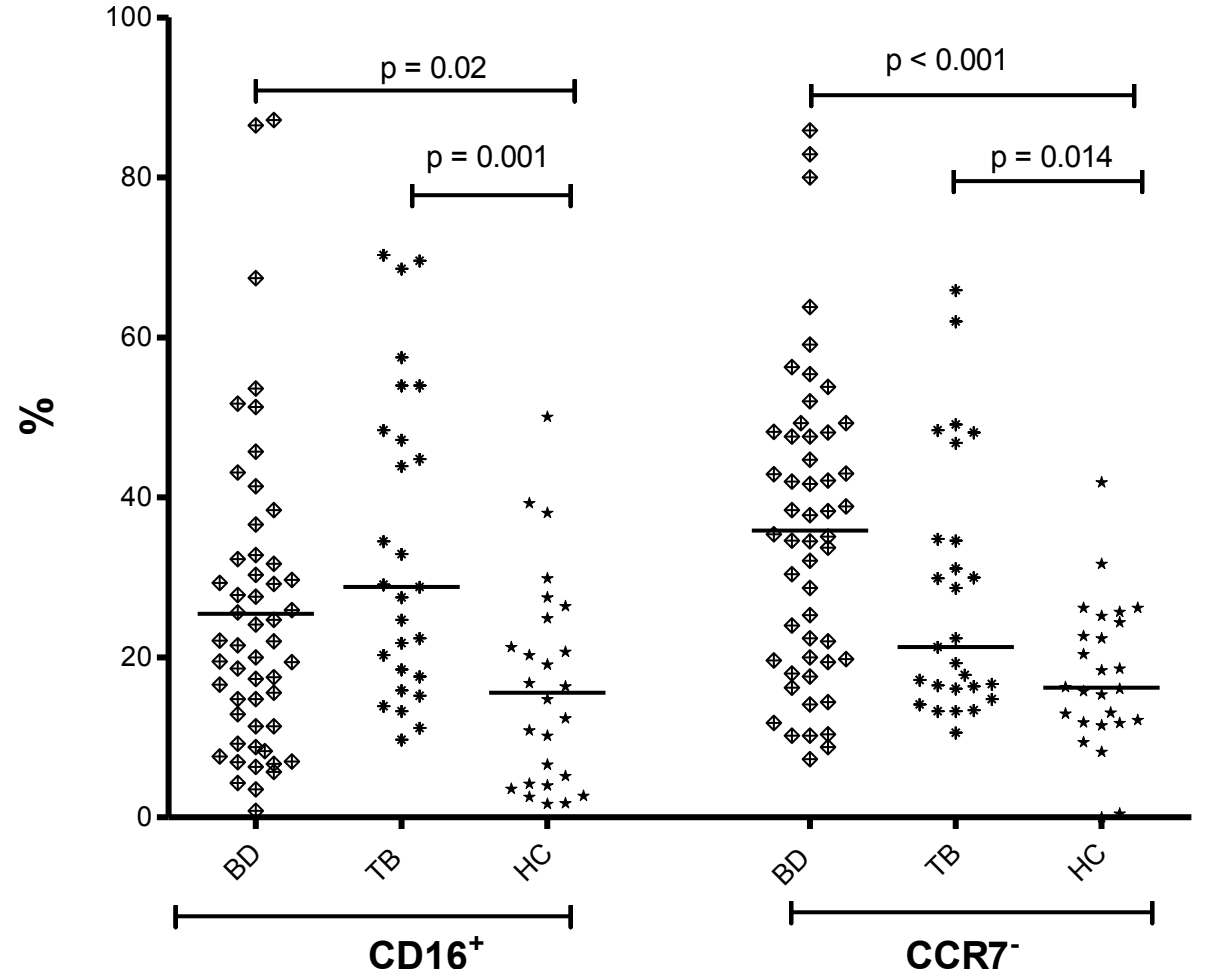

Figure $1 \mathrm{CD}^{-} 6^{+}$or $\mathrm{CCR7}{ }^{-T C R V} \delta 2^{+} \mathrm{T}$ cells. The proportion of $\mathrm{TCRV} \delta 2^{+} \mathrm{T}$ cells carrying CD16 or lacking CCR7 in the peripheral blood of $70 \mathrm{BD}$ (38 A-BD, $32 \mathrm{IA}-\mathrm{BD}), 27 \mathrm{~TB}$ patients and $30 \mathrm{HC}$. The differences of $\mathrm{BD}$ and TB with $\mathrm{HC}$ were significant $(P=0.02$ and $P=0.001$, and $P<0.001$ and $P=0.014$, respectively).

the BD group compared to the $\mathrm{HC}(0.5$ vs. $0.3 \%, P=$ 0.008). Namely, the $\mathrm{NKG}_{2} \mathrm{C}^{+}$fraction of pan $\gamma \delta^{+} \mathrm{T}$ cells was increased in $\mathrm{BD}$ compared to controls without reaching statistical significance (13.5 vs. $11.3 \%)$. The relative increase of $\mathrm{NKG}_{2} \mathrm{C}^{+} \gamma \delta^{+} \mathrm{T}$ cells was also detected in TB (0.6\% of PB lymphocytes, $P=0.018$, and $14.3 \%$ of $\gamma \delta^{+}$ $\mathrm{T}$ cells, Table 2).

TCRV $\gamma 9 \mathrm{~V} \delta 2^{+} \mathrm{T}$ cells can also be activated through NKG2D independently of antigen [21] or by ligands of NKG2D, that is, MICA or MICB, which are often induced by stress [22]. NKG2D receptors on the $\gamma \delta \mathrm{T}$ cells, however, were decreased in patients with $\mathrm{BD}$ and TB compared to $\mathrm{HC}$ (77.7 and 75.8 vs. $87.5 \%, P=0.001$ and 0.004, Figure 2).

CCR7 is used to distinguish tissue-homing effector and lymph node-homing non-effector memory cells [23]. When expression of CCR7 was investigated, CCR7 $7^{-}$of TCRV $\delta 2^{+}$cells were increased in BD compared to HC (32.2 vs. $17.7 \%, P<0.001$ ) implicating an increase of effector $\gamma \delta \mathrm{T}$ cell phenotype in the periphery by losing their CCR7 [24]. These CCR7 $\gamma \delta$ T cells were also more frequent in $\mathrm{PB}$ of $\mathrm{TB}$ patients compared to $\mathrm{HC}$ (27.9\%, $P=0.014$, Figure 1 ).
These data showed, despite the comparable number of $\gamma \delta \mathrm{T}$ cells in $\mathrm{BD}$ as in $\mathrm{HC}$, that increased proportions of $\mathrm{CD}_{16}{ }^{+}, \mathrm{NKG}_{2} \mathrm{C}^{+}$or CCR7 ${ }^{-} \gamma \delta^{+} \mathrm{T}$ cells with an effector phenotype were evident in $\mathrm{BD}$ as well as in $\mathrm{TB}$.

\section{In vitro cytokine and chemokine responses of short-term} $\gamma \delta^{+} T$ cell lines

To evaluate the effector functions, such as in vitro expansion capability and cytokine activity of $\gamma \delta \mathrm{T}$ cells in BD, phosphoantigen analog BrHPP was used to stimulate these cells and responsive cells were propagated with IL-2. From the $\gamma \delta \mathrm{T}$ cell cultures of $70 \mathrm{BD}$ and $27 \mathrm{~TB}$ patients and 30 $\mathrm{HC}$ donors, $55.7 \%$ (50\% in A-BD and $62.5 \%$ in IA-BD), $33.3 \%$ and $70 \%$ could be expanded up to $>70 \%$ TCRV $\delta 2^{+}$ at the eighth day in vitro, respectively. The mean expansion ratio of BD patients was lower in A-BD than IA-BD and in $\mathrm{HC}$ without statistical significance. However, this expandability of cells was significantly lower in TB patients compared to HC $(P=0.008)$ (Figure 3$)$. The expanded $\gamma \delta$ $\mathrm{T}$ cells were used further in vitro to compare their responsiveness to stimuli by cytokine secretion.

When stimulated with phosphoantigens via TCR, various cytokine and chemokine production can be induced 


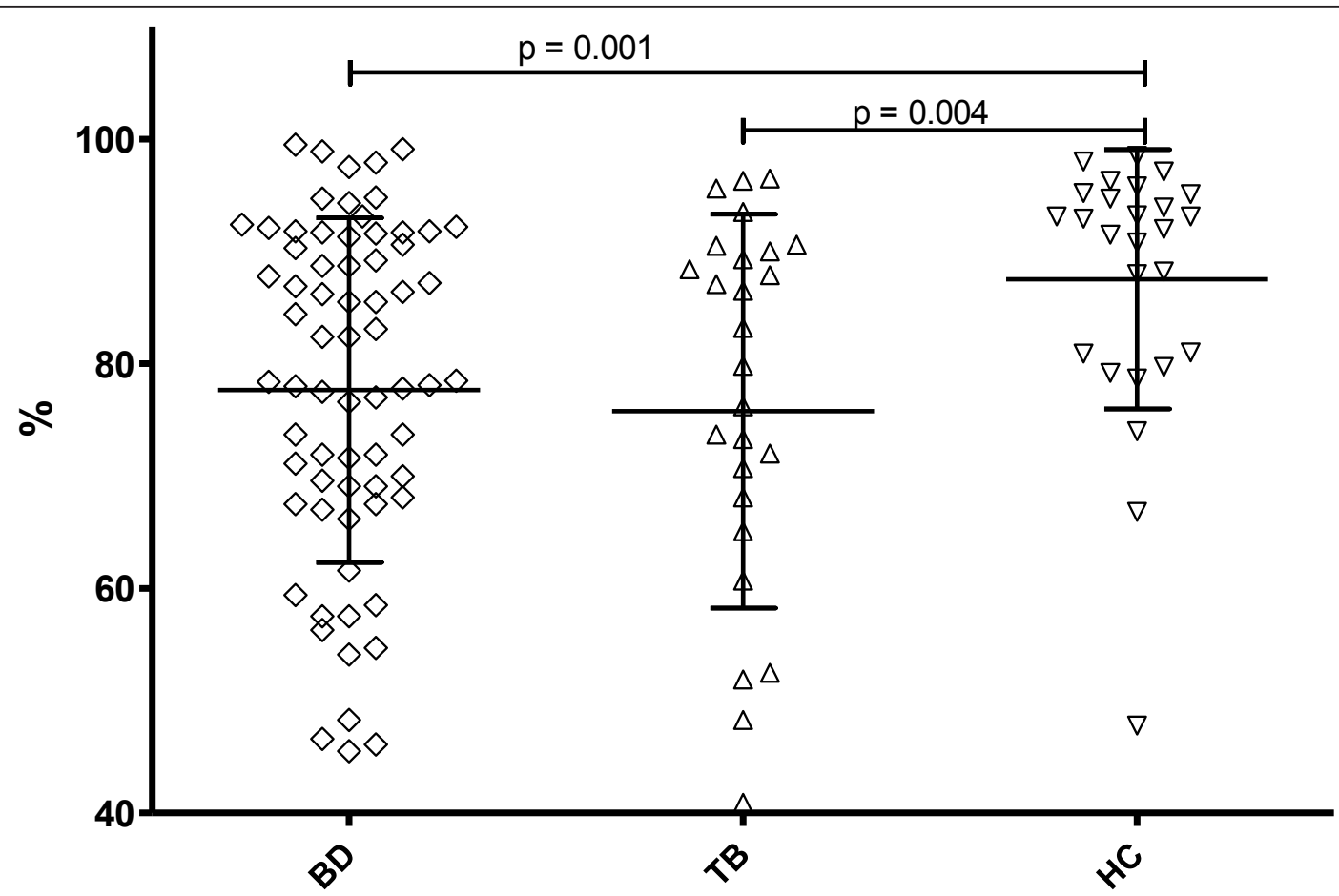

Figure 2 TCR $\boldsymbol{\gamma} \boldsymbol{\delta}^{+}$T cells carrying NKG2D. The \% of TCR $\gamma \delta^{+} T$ cells carrying NKG2D in the peripheral blood of 70 BD (38 A-BD, 32 IA-BD), 27 $\mathrm{TB}$ patients and $30 \mathrm{HC}$. The differences between $\mathrm{BD}$ and TB to $\mathrm{HC}$ were significant $(P=0.001$ and $P=0.004)$.

in $\gamma \delta \mathrm{T}$ cells [25]. Phosphoantigen reactive $\gamma \delta \mathrm{T}$ cells represented a type-1 polarized subset secreting IFN- $\gamma$ and TNF- $\alpha$ [26]. Expanded $\gamma \delta$ T cells of patients and controls containing over $70 \% \gamma \delta \mathrm{T}$ cells (short-term $\gamma \delta \mathrm{T}$ cell lines) were restimulated by TCR and compared for cytokine and chemokine secretions in culture supernatants from $42 \mathrm{BD}$, 9 TB patients and 20 HCs. The phosphoantigen re-stimulation induced in these short-term $\gamma \delta \mathrm{T}$ cell lines to produce higher levels of IFN- $\gamma$, GM-CSF, IL-13, TNF- $\alpha$ as

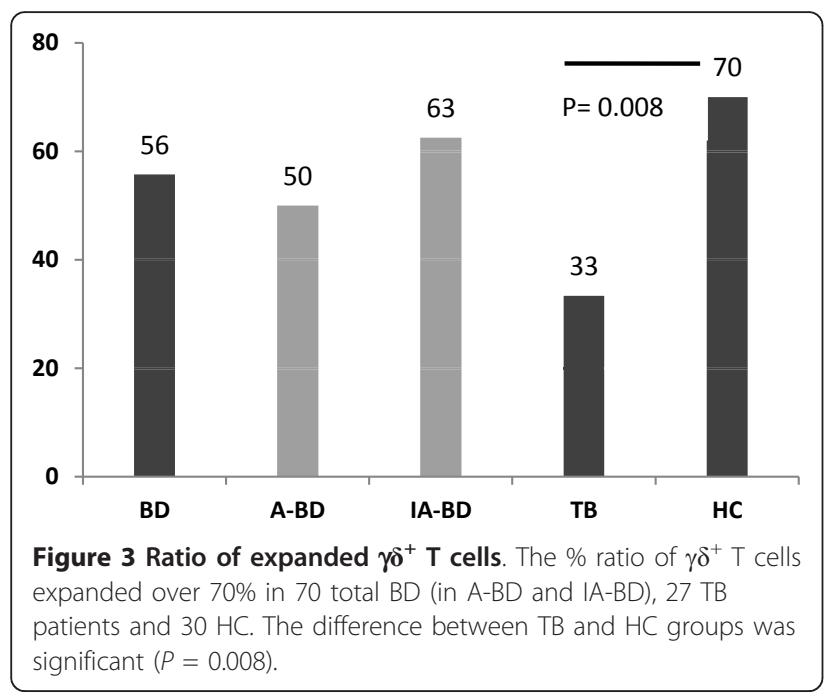

well as CCL4 (MIP1- $\beta$ ) and CCL5 (RANTES) in all patient and control groups (Additional file 1, Figure S1 shows the results in $\mathrm{HC}$ ). Induction of IFN- $\gamma$ and IL-13 production of short-term $\gamma \delta \mathrm{T}$ cell lines by TCR (BrHPP) re-stimulation did not differ among groups, whereas GM-CSF, TNF- $\alpha$, CCL 4 and CCL 5 production was lower in BD compared to HC ( $P=0.02,0.015,0.05$, respectively).

An interaction of TCR- and TLR-signaling is shown to enhance effector functions of human PB $\gamma \delta$ T cells. To investigate the activating or co-stimulating properties of TLR3 on $\gamma \delta$ T cells, a TLR3 ligand was added to the cells at the re-stimulation stage to mimic the responses to specific and non-specific stimulations. The re-stimulation with TCR and TLR3 agonist simultaneously induced significantly lower levels of IFN- $\gamma$, IL-13, TNF- $\alpha$, as well as GMCSF, CCL4 and CCL5, in BD than in HC ( $P=0.008,0.029$ and $0.021,0.018,0.012$ and 0.044 , respectively) (Figure 4).

As $42 \%$ of the patients were on immunosuppressive treatment at the time of blood sampling, we compared the patients with or without treatment to see the possible effect of treatment. The responses to TCR stimulation did not show a significant difference between the groups receiving a treatment or not.

\section{Discussion}

$\gamma \delta \mathrm{T}$ cells have been evaluated in $\mathrm{BD}$ in various studies with a possible role in bridging the innate and adaptive 


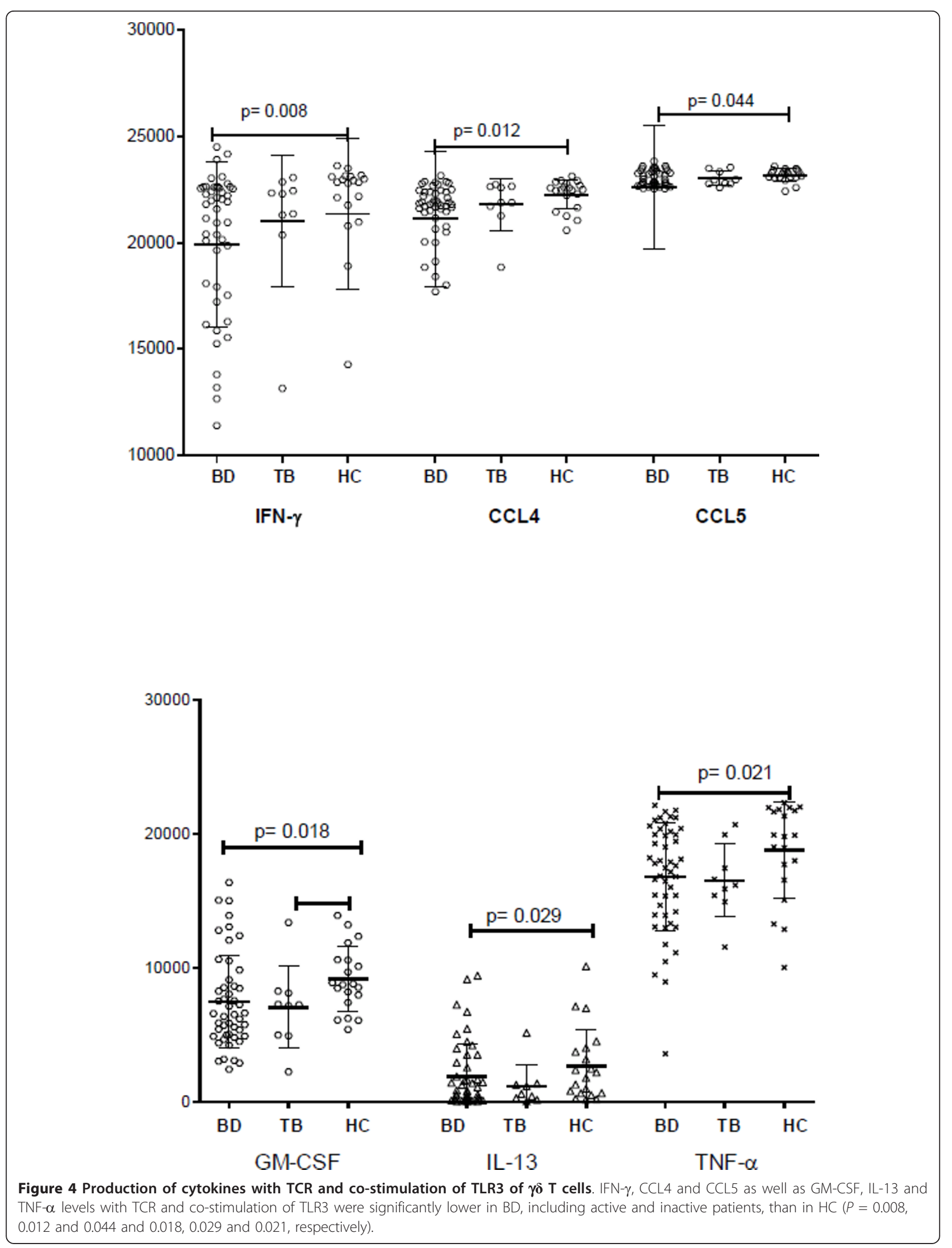


immune activations and functioning as a local defense response inducing activation of other immune cell populations. Data such as tissue infiltrations of $\gamma \delta \mathrm{T}$ cells in erythema nodosum-like lesions of BD patients suggested a role for $\gamma \delta$ T cells in disease pathogenesis. In this study, $\gamma \delta$ $\mathrm{T}$ cells are evaluated in $\mathrm{BD}$ and as a disease control group in TB for their activation state and for their functional activities in response to stimuli.

When the presence of this rare cell population in $\mathrm{BD}$ is compared to healthy individuals, conflicting results have been published with $[13,14,27]$ and without $[16,28]$ increased levels in the $\mathrm{PB}$, with a predominantly disease exacerbation-related increase in recent studies [14,17]. In the present study, which investigated a relatively higher number of BD patients, $\gamma \delta$ T cells were only slightly increased in the blood of the patients.

The discrepancy among the previous studies about the number of $\gamma \delta \mathrm{T}$ cells in PB might be due to the activation status of the disease, as reflection of local tissue inflammation to PB might be variable due to factors such as the disease severity or immunosuppressive medications. Even acute-phase response (erythrocyte sedimentation rate (ESR), C-reactive protein (CRP)), which is the hallmark of inflammation, is not a reliable biomarker in BD and elevated only in relation to a limited number of disease manifestations, such as arthritis or some skin lesions of the disease. Similar to our results, in a previous study, although lesional skin of patients with BD had significantly increased $\gamma \delta \mathrm{T}$ cells, peripheral blood $\gamma \delta \mathrm{T}$ cells counts were similar in BD and control groups [29].

Despite the dominance of the TCRV $\delta 2^{+}$subtype among the $\gamma \delta \mathrm{T}$ cells in BD patients similar to previous reports [30], we found a decrease of TCRV $\delta 2^{+}$proportion of $\gamma \delta$ $\mathrm{T}$ cells in BD compared to HC. Considering $\gamma \delta$ T cells as an effector cell type against mycobacterial antigens, TB patients had also relatively low $\gamma \delta \mathrm{T}$ cells and lower proportions of TCRV $\delta 2^{+} \mathrm{T}$ cells among pan $\gamma \delta$ T cells.

In $\mathrm{BD}, \mathrm{PB} \gamma \delta \mathrm{T}$ cells expressed early activation markers and secreted Th1 and proinflammatory cytokines. Bacteria-specific KTH-1 responsive $\gamma \delta \mathrm{T}$ cell lines have been demonstrated to be pro-inflammatory, as well. Significantly greater proportions of the $\mathrm{V} \delta 1^{+}$and $\mathrm{V} \delta 2^{+} \gamma \delta \mathrm{T}$ cell subsets were activated in patients with active BD; however, the balance of activation favored $\mathrm{V} \delta 1^{+} \mathrm{T}$ cells [31]. In this present study, we have not evaluated $\mathrm{V} \delta 1^{+} \mathrm{T}$ cells separately; however, the total number of the $\gamma \delta \mathrm{T}$ cells was not increased, suggesting their relatively low increase, if any, as well. As $\gamma \delta \mathrm{T}$ cells are more likely to be tissue resident and relatively rare in the blood, the phenotypic differences observed between studies may be related to wide distribution features of cells in systemic circulation and tissues.

Based on previous data of the activated status of $\gamma \delta$ $\mathrm{T}$ cells in $\mathrm{BD}$ [17], when phenotypic markers for effector cells were evaluated, the data revealed an increased activation status of the $\gamma \delta \mathrm{T}$ cells in BD and also in TB. The elevation of Fc $\gamma$ RIII (CD16) expression on $\gamma \delta \mathrm{T}$ cells was in accordance with some autoimmune diseases, such as Sjogren's syndrome or MS [32,33]. Similarly, effector or central memory $\mathrm{T}$ subtypes are proposed for $\gamma \delta \mathrm{T}$ cells based on their CCR7 expression [34]. $\gamma \delta \mathrm{T}$ cell activation results in an immediate acquisition of secondary lymphoid tissue-homing capabilities, including CCR7 expression, which decline afterwards [35]. A relative increase of $\gamma \delta \mathrm{T}$ cells without the lymphoid homing receptor emphasizes effector features of these cells based on not a recent activation in $\mathrm{BD}$ as well as in $\mathrm{TB}$ compared to $\mathrm{HC}$. IFN $-\gamma$ producing $\gamma \delta \mathrm{T}$ cells in response to mycobacterium antigen also had mostly an effector memory cell phenotype of CD45RA ${ }^{-}$CCR7 ${ }^{-}$in a recent study [36].

$\gamma \delta \mathrm{T}$ cells appear to play a predominant role against mycobacterium tuberculosis infection and produce IFN- $\gamma$ strongly and early in response to mycobacterial phosphoantigens $[37,38]$. These cells, however, are quantitatively and functionally impaired by mycobacterial infection; the percentage of the V $\delta 2$ subset was found to be lower in patients with TB than in controls [39] creating an imbalance between the V $\delta 1$ and the normally predominant $\mathrm{V} \delta 2^{+}$subsets and $\mathrm{V} \delta 2^{+}$anergy [40]. Reduced circulating $\mathrm{V} \gamma 9 \mathrm{~V} \delta 2^{+} \mathrm{T}$ cell effectors in patients with acute pulmonary tuberculosis resulted in a reduced frequency of IFN- $\gamma$-producing cells after stimulation with nonpeptidic mycobacterial ligands as well [41]. TCRV $\delta 2^{+} \mathrm{T}$ cells in $\mathrm{BD}$ resemble these cells with down-regulated status in $\mathrm{PB}$.

$\gamma \delta \mathrm{T}$ cell effector function is also modulated by inhibitory and activating NK receptors. A large fraction of circulating $\mathrm{V} \gamma 9 \mathrm{~V} \delta 2 \mathrm{~T}$ cells express MHC class I receptors, mostly the inhibitory CD94/NKG2A complex. Triggering of this receptor down-modulates activation of the $\gamma \delta$ TCR and inhibits $\gamma \delta$ T cell proliferation and IFN- $\gamma$ and TNF- $\alpha$ production in response to microbial phosphorylated ligands representing a mechanism to control self-reactivity of $\gamma \delta \mathrm{T}$ cells. Following stimulation with mycobacterial ligands, the CD94/NKG2A complex has been shown to rapidly translocate to the cell membrane on $\mathrm{V} \delta 2^{+}$cells, leading to inhibition of cell activation [42]. In the present data from $\mathrm{BD}$ and $\mathrm{TB}$ patients, inhibitory regulation of $\mathrm{V} \delta 2^{+} \mathrm{T}$ cells was not up-regulated, but the small number of activating receptor $\mathrm{NKG}_{2} \mathrm{C}^{+} \gamma \delta \mathrm{T}$ cells were relatively increased, implicating not a recent activation inducing NKG2A on $\delta 2^{+} \mathrm{T}$ cells.

Human $V \delta 2^{+}$subset of $\gamma \delta \mathrm{T}$ cells can co-express both activating and inhibitory NK receptors with Fc $\gamma$ RIII (CD16). CD94/NKG2C complex is functional with IFN- $\gamma$ production, $\mathrm{T}$ cell proliferation and cytolytic activity, whereas NKG2A expression was found on all $\gamma \delta \mathrm{T}$ cell memory subsets, suggesting a crucial role of the inhibitory 
signal provided by this receptor on $\gamma \delta \mathrm{T}$ cell responses [20]. In BD and in A-BD a slight increase of activating $\mathrm{NKG}_{2} \mathrm{C}^{+} \gamma \delta \mathrm{T}$ cells has been detected showing an activation status of the cells, although the other activating receptor, NKG2D, was decreased in BD. Both of these changes were also detected in the TB group, suggesting similar functional changes of $\gamma \delta \mathrm{T}$ cells in both diseases.

Functional alterations in $\mathrm{BD}$ were evident as the expansion ratio of $\gamma \delta \mathrm{T}$ cells was significantly lower in $\mathrm{BD}$ and more so in TB, implicating an unresponsiveness of these cells for re-stimulation in vitro. That was contrary to the previous data on $\mathrm{BD}$, as the expansion factor of $\gamma \delta \mathrm{T}$ cells was greater in patients with active disease than in those with inactive disease or in control individuals [17], which we did not replicate.

$\mathrm{V} \delta 2^{+} \mathrm{T}$ cells have been shown to regulate other cells by secretion of cytokines and chemokines, such as CCL4 and CCL5 [6,25], in response to components of bacterial cell walls, supporting a role for these cells in the early stages of the inflammatory responses to many common pathogens. However, the GM-CSF, CCL4, CCL5 and TNF- $\alpha$ responses of the expanded cells to TCR stimulation was lower in BD, especially in IA-BD patients as in TB. This low response could be the result of the in vitro expansion step, which may have caused an anergy in these cells. But also an in vivo exhaustion of $\gamma \delta \mathrm{T}$ cells could not be ruled out, although the expandability of the cells points to their capability to respond to antigenic stimulation in vitro [40].

Although TLR3 is not expressed on the cell surface of freshly isolated $\gamma \delta \mathrm{T}$ cells, the co-stimulatory effect of TLR3 ligation has been shown and it is up-regulated after TCR-stimulation and increased IFN- $\gamma$ secretion [12]. We assumed that activation and expansion of $\gamma \delta \mathrm{T}$ cells before co-stimulation with TLR3 agonists, could reveal the effect of TLR3 ligand at the re-stimulation in our system. However, the results showed that the short-term $\mathrm{T}$ cell lines of $\mathrm{BD}$ patients responded with less cytokine secretion to TCR and TLR than HC. Similar to our results, the response of expanded $\gamma \delta \mathrm{T}$ cells to TLR ligand co-stimulation has been shown to be somehow lower than TCR/TLR3 ligand stimulated freshly isolated $\gamma \delta \mathrm{T}$ cells [10]. This effect was even more pronounced in BD patients.

The functional data presented are derived from PB cells expanded in vitro before testing. Due to the low number of $\gamma \delta \mathrm{T}$ cells in $\mathrm{PB}$, in vitro manipulation and stimulation has been undertaken. However, with the expansion cutoff, we also had to measure the activity of $30 \%$ non- $\gamma \delta$ $\mathrm{T}$ cells, which could not be avoided and limits the interpretation of this functional data.

The results only represent a subset of $\gamma \delta \mathrm{T}$ cells as mainly $\mathrm{V} \gamma 9 \mathrm{~V} \delta 2 \mathrm{~T}$ cells are responding to phosphoantigens and expand in culture. This subgroup has become the most widely studied $\gamma \delta \mathrm{T}$ cell population as they are readily accessible in human blood, easy to culture and expand in vitro and are of direct relevance for infection [43]. Another disadvantage of in vitro stimulation with phosphoantigens may be the induction of inhibitory receptors on $\gamma \delta \mathrm{T}$ cells, which may modulate their response in disease state differentially than $\mathrm{HC}$ [44].

The activation of $\gamma \delta$ T cells can be cytolytic or inflammatory by secretion of cytokines [45]. Previous studies pointed to a role of activated $\gamma \delta$ T cells in $\mathrm{BD}[17,31,46]$. The present study did not provide evidence for an increase of $\gamma \delta \mathrm{T}$ cells in active BD patients, although functional changes implicated by surface receptors are shown in BD.

A major limitation of our study is the assessment of $\gamma \delta$ $\mathrm{T}$ cells function with limited stimulation in an in vitro culture system. Other PB cell subsets and cytokines/chemokines might influence the response of $\gamma \delta \mathrm{T}$ cells. With different methodology, such as single-cell experiments and measurement of mRNA expressions, role and function of $\gamma \delta \mathrm{T}$ cells in BD pathogenesis might be further clarified.

\section{Conclusions}

In the present study no increase of $\gamma \delta \mathrm{T}$ cells was detected in active BD patients. However, based on surface receptors on $\gamma \delta \mathrm{T}$ cells, functional changes of these cells were implicated. When TCRV $\delta 2^{+} \mathrm{T}$ cells were expanded and tested for the response to TCR and TLR stimulations, cytokine and chemokine secretions were found impaired in $\mathrm{BD}$.

\section{Additional material}

Additional file 1: Figure S1. Induced GM-CSF, IFN- $\gamma, I L-13, C C L 4, C C L 5$ and TNF- $\alpha$ levels with TCR alone and with additional co-stimulation of TLR3 agonist are shown in the HC group $(n=20)$.

\section{Abbreviations \\ A-BD: active BD; BD: Behcet's disease; BrHPP: bromohydrin pyrophosphate; CRP: C-reactive protein; ESR: erythrocyte sedimentation rate; GM-CSF: granulocyte monocyte colony stimulating factor; $\mathrm{HC}$ : healthy control; IA-BD: inactive BD; IFN: interferon; IL: interleukin; IPP: isopentenyl pyrophosphate; mAb: monoclonal antibodies; MS: multiple sclerosis; PB: peripheral blood; PBMCs: peripheral blood mononuclear cells; PPD: purified protein derivative; RANTES: Regulated on Activation, Normal T Expressed and Secreted; TB: tuberculosis; TCR: T cell receptors; TNF: tumor necrosis factor.}

\section{Authors' contributions}

GP and EG participated in patient data collection, performed phenotyping and cell culture, interpreted and analyzed the data, and wrote the manuscript. BE and ZK participated in the design of the study, sample and data collection from the patient groups, interpretation of the data and manuscript preparation. AG, HD and GSD designed and coordinated the study, analyzed and interpreted the data, and wrote the manuscript. All authors read and approved the final manuscript for publication.

\section{Competing interests}

The authors declare that they have no competing interests. 


\section{Acknowledgements}

We thank Helene Sicard from Innate Pharma, Marseille, France, for kindly providing us with BrHPP. This study is funded by Istanbul University Research Fund (BAP-501).

\section{Author details}

'Istanbul Medical Faculty, Istanbul University, Millet Caddesi, Çapa, Istanbul, 34093 Turkey. ${ }^{2}$ Division of Rheumatology, Department of Internal Medicine, Istanbul Medical Faculty, Istanbul University, Millet Caddesi, Çapa, Istanbul, 34093 Turkey. ${ }^{3}$ Department of Pulmonary Diseases, Istanbul Medical Faculty, Istanbul University, Millet Caddesi, Çapa, Istanbul, 34093 Turkey. ${ }^{4}$ Division of Rheumatology, Department of Internal Medicine, Marmara University, School of Medicine Hospital, Fevzi Çakmak Mahallesi, Mimar Sinan Caddesi, No: 41, Pendik, Istanbul, 34890 Turkey. ${ }^{5}$ Department of Physiology, Istanbul Medical Faculty, Istanbul University, Millet Caddesi, Çapa, Istanbul, 34093 Turkey.

Received: 10 October 2012 Revised: 26 December 2012

Accepted: 9 January 2013 Published: 21 January 2013

\section{References}

1. Direskeneli H: Behcet's disease: infectious aetiology, new autoantigens, and HLA-B51. Ann Rheum Dis 2001, 60:996-1002.

2. Zierhut M, Mizuki N, Ohno S, Inoko H, Gul A, Onoe K, Isogai E: Immunology and functional genomics of Behcet's disease. Cell Mol Life Sci 2003, 60:1903-1922

3. Remmers EF, Cosan F, Kirino Y, Ombrello MJ, Abaci N, Satorius C, Le JM, Yang B, Korman BD, Cakiris A, Aglar O, Emrence Z, Azakli H, Ustek D, TugalTutkun I, Akman-Demir G, Chen W, Amos Cl, Dizon MB, Kose AA, Azizlerli G, Erer B, Brand OJ, Kaklamani VG, Kaklamanis P, Ben-Chetrit E, Stanford M, Fortune F, Ghabra M, Ollier WE, et al: Genome-wide association study identifies variants in the MHC class I, IL10, and IL23R-IL12RB2 regions associated with Behcet's disease. Nat Genet 2010, 42:698-702.

4. Constant P, Davodeau F, Peyrat MA, Poquet Y, Puzo G, Bonneville M, Fournie JJ: Stimulation of human $\gamma \delta$ T cells by nonpeptidic mycobacterial ligands. Science 1994, 264:267-270.

5. Lafont V, Liautard J, Sable-Teychene M, Sainte-Marie Y, Favero J: Isopentenyl pyrophosphate, a mycobacterial non-peptidic antigen triggers delayed and highly sustained signaling in human $\gamma \delta T$ lymphocytes without inducing down-modulation of $\mathrm{T}$ cell antigen receptor. J Biol Chem 2001, 276:15961-15967.

6. Eberl M, Engel R, Beck E, Jomaa H: Differentiation of human $\gamma \delta \mathrm{T}$ cells towards distinct memory phenotypes. Cell Immunol 2002, 218:1-6.

7. Angelini DF, Borsellino G, Poupot M, Diamantini A, Poupot R, Bernardi G, Poccia F, Fournie JJ, Battistini L: FcgammaRIII discriminates between 2 subsets of $V_{Y} 9 \mathrm{~V} \delta 2$ effector cells with different responses and activation pathways. Blood 2004, 104:1801-1807.

8. Lazetic S, Chang C, Houchins JP, Lanier LL, Phillips JH: Human natural killer cell receptors involved in MHC class I recognition are disulfide-linked heterodimers of CD94 and NKG2 subunits. J Immunol 1996, 157:4741-4745.

9. Halary F, Peyrat MA, Champagne E, Lopez-Botet M, Moretta A, Moretta L, Vie H, Fournie JJ, Bonneville M: Control of self-reactive cytotoxic T lymphocytes expressing $\gamma \delta \mathrm{T}$ cell receptors by natural killer inhibitory receptors. Eur J Immunol 1997, 27:2812-2821.

10. Wesch D, Peters C, Oberg HH, Pietschmann K, Kabelitz D: Modulation of $\gamma \delta$ T cell responses by TLR ligands. Cell Mol Life Sci 2011, 68:2357-2370.

11. Hedges JF, Lubick KJ, Jutila MA: $\gamma \delta T$ cells respond directly to pathogenassociated molecular patterns. J Immunol 2005, 174:6045-6053.

12. Wesch D, Beetz S, Oberg H-H, Marget M, Krengel K, Kabelitz D: Direct costimulatory effect of TLR3 Ligand poly(l:C) on human $\gamma \delta \mathrm{T}$ lymphocytes. J Immunol 2006, 176:1348-1354.

13. Fortune $F$, Walker J, Lehner T: The expression of $\gamma \delta T$ cell receptor and the prevalence of primed, activated and IgA-bound T cells in Behcet's syndrome. Clin Exp Immunol 1990, 82:326-332.

14. Bank I, Duvdevani M, Livneh A: Expansion of $\gamma \delta$ T-cells in Behcet's disease: role of disease activity and microbial flora in oral ulcers. J Lab Clin Med 2003, 141:33-40

15. Freysdottir J, Lau S, Fortune F: $\gamma \delta$ T cells in Behcet's disease (BD) and recurrent aphthous stomatitis (RAS). Clin Exp Immunol 1999, 118:451-457.

16. Verjans GM, van Hagen PM, van der Kooi A, Osterhaus AD, Baarsma GS: Vү9V $22 \mathrm{~T}$ cells recovered from eyes of patients with Behcet's disease recognize non-peptide prenyl pyrophosphate antigens. J Neuroimmunol 2002, 130:46-54

17. Triolo G, Accardo-Palumbo A, Dieli F, Ciccia F, Ferrante A, Giardina E, Sano CD, Licata G: Vy9/Vס2 T lymphocytes in Italian patients with Behcet's disease: evidence for expansion, and tumour necrosis factor receptor II and interleukin-12 receptor beta1 expression in active disease. Arthritis Res Ther 2003, 5:R262-R268.

18. Kulaber A, Tugal-Tutkun I, Yentur SP, Akman-Demir G, Kaneko F, Gul A, Saruhan-Direskeneli G: Pro-inflammatory cellular immune response in Behcet's disease. Rheumat Int 2007, 27:1113-1118.

19. International Study Group for Behçet's Disease: Criteria for diagnosis of Behçet's disease. Lancet 1990, 335:1078-1080.

20. Angelini DF, Zambello R, Galandrini R, Diamantini A, Placido R, Micucci F, Poccia F, Semenzato G, Borsellino G, Santoni A, Battistini L: NKG2A inhibits NKG2C effector functions of $\gamma \delta$ T cells: implications in health and disease. J Leukoc Biol 2011, 89:75-84

21. Rincon-Orozco B, Kunzmann V, Wrobel P, Kabelitz D, Steinle A, Herrmann T: Activation of V\{y9V82 T cells by NKG2D. J Immunol 2005, 175:2144-2151.

22. Raulet DH: Roles of the NKG2D immunoreceptor and its ligands. Nat Rev Immunol 2003, 3:781-790.

23. Sallusto F, Mackay CR, Lanzavecchia A: The role of chemokine receptors in primary, effector, and memory immune responses. Annu Rev Immunol 2000, 18:593-620.

24. Moser B, Loetscher P: Lymphocyte traffic control by chemokines. Nat Immunol 2001, 2:123-128.

25. Cipriani B, Borsellino G, Poccia F, Placido R, Tramonti D, Bach S, Battistini L, Brosnan CF: Activation of C-C beta chemokines in human peripheral blood $\gamma \delta T$ cells by isopentenyl pyrophosphate and regulation by cytokines. Blood 2000, 95:39-47.

26. Dagna L, lellem A, Biswas P, Resta D, Tantardini F, Fortis C, Sabbadini MG, D'Ambrosio D, Manfredi AA, Ferrarini M: Skewing of cytotoxic activity and chemokine production, but not of chemokine receptor expression, in

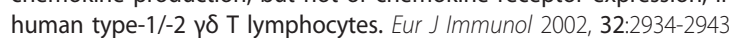

27. Suzuki Y, Hoshi K, Matsuda T, Mizushima Y: Increased peripheral blood $\gamma \delta^{+}$ T cells and natural killer cells in Behcet's disease. J Rheumatol 1992, 19:588-592.

28. Ergun T, Eksioglu-Demiralp E, Direskeneli H, Mumcu G, Gurbuz O: TCR $\gamma \delta(+)$ $\mathrm{T}$-cell response to streptococcal antigens in patients with psoriasis. Arch Dermatol Res 2005, 296:536-538.

29. Ergun T, Ince U, Eksioglu-Demiralp E, Direskeneli H, Gurbuz O, Gurses L, Aker F, Akoglu T: HSP 60 expression in mucocutaneous lesions of Behcet's disease. J Am Acad Dermatol 2001, 45:904-909.

30. Freysdottir J, Hussain L, Farmer I, Lau SH, Fortune F: Diversity of $\gamma \delta$ T cells in patients with Behcet's disease is indicative of polyclonal activation. Oral Dis 2006, 12:271-277.

31. Yasuoka H, Yamaguchi Y, Mizuki N, Nishida T, Kawakami Y, Kuwana M: Preferential activation of circulating CD8+ and $\gamma \delta T$ cells in patients with active Behcet's disease and HLA-B51. Clin Exp Rheumatol 2008, 26:S59-63.

32. Lamour A, Smith MD, Lydyard PM, Youinou PY: The majority of FcyRlllpositive $\gamma \delta T$ cells do not express HLA-DR in patients with primary Sjogren's syndrome. Immunol Lett 1995, 45:153-155.

33. Chen Z, Freedman MS: Correlation of specialized CD16(+)yठ T cells with disease course and severity in multiple sclerosis. J Neuroimmunol 2008, 194:147-152.

34. Glatzel A, Wesch D, Schiemann F, Brandt E, Janssen O, Kabelitz D: Patterns of chemokine receptor expression on peripheral blood $\gamma \delta T$ lymphocytes: strong expression of CCR5 Is a selective feature of V82/ Vү9 үठ T Cells. J Immunol 2002, 168:4920-4929.

35. Brandes M, Willimann K, Lang AB, Nam K-H, Jin C, Brenner MB, Morita CT, Moser $B$ : Flexible migration program regulates $\gamma \delta$ T-cell involvement in humoral immunity. Blood 2003, 102:3693-3701.

36. Li L, Wu C-Y: CD4+CD25+ Treg cells inhibit human memory $\gamma \delta T$ cells to produce IFN- $\gamma$ in response to M tuberculosis antigen ESAT-6. Blood 2008, 111:5629-5636.

37. Tanaka Y, Morita C, Nieves E, Brenner M, Bloom B: Natural and synthetic non peptide antigens recognized by human $\gamma \delta$ T cells. Nature 1995, 375:155-158.

38. Shen Y, Zhou D, Qiu L, Lai X, Simon M, Shen L, Kou Z, Wang Q, Jiang L, Estep J, Hunt R, Clagett M, Sehgal PK, Li Y, Zeng X, Morita CT, Brenner MB, Letvin NL, Chen ZW: Adaptive immune response of Vy2V $\delta 2+T$ cells during mycobacterial infections. Science 2002, 295:2255-2258. 
39. Carvalho AC, Matteelli A, Airò P, Tedoldi S, Casalini C, Imberti L, Cadeo GP, Beltrame A, Carosi G: $\gamma \delta \mathrm{T}$ lymphocytes in the peripheral blood of patients with tuberculosis with and without HIV co-infection. Thorax 2002, 57:357-360.

40. Rojas RE, Chervenak KA, Thomas J, Morrow J, Nshuti L, Zalwango S, Mugerwa RD, Thiel BA, Whalen CC, Boom WH: V $\delta 2+\gamma \delta$ T cell function in Mycobacterium tuberculosis+ and HIV-1+positive patients in the United States and Uganda: application of a whole-blood assay. J Infect Dis 2005, 192:1806-1814.

41. Gioia C, Agrati C, Casetti R, Cairo C, Borsellino G, Battistini L, Mancino G, Goletti D, Colizzi V, Pucillo LP, Poccia F: Lack of CD27-CD45RA-Vy9V82+ T cell effectors in immunocompromised hosts and during active pulmonary tuberculosis. J Immunol 2002, 168:1484-1489.

42. Boullier S, Poquet Y, Halary F, Bonneville M, Fournie JJ, Gougeon ML: Phosphoantigen activation induces surface translocation of intracellular CD94/NKG2A class I receptor on CD94- peripheral Vү9V82 T cells but not on CD94- thymic or mature gammadelta T cell clones. Eur I Immunol 1998, 28:3399-3410.

43. Riganti C, Massaia M, Davey MS, Eberl M: Human $\gamma \delta$ T-cell responses in infection and immunotherapy: common mechanisms, common mediators? Eur J Immunol 42:1668-1676.

44. Poccia F, Cipriani B, Vendetti S, Colizzi V, Poquet Y, Battistini L, LopezBotet M, Fournie J, Gougeon M: CD94/NKG2 inhibitory receptor complex modulates both anti-viral and anti-tumoral responses of polyclonal phosphoantigen-reactive Vy9V82 T lymphocytes. J Immunol 1997, 159:6009-6017.

45. Agrati C, Cimini E, Sacchi A, Bordoni V, Gioia C, Casetti R, Turchi F, Tripodi M, Martini F: Activated Vy9Vס2 T cells trigger granulocyte functions via MCP-2 release. J Immunol 2009, 182:522-529.

46. Accardo-Palumbo A, Ferrante A, Cadelo M, Ciccia F, Parrinello G, Lipari L, Giardina AR, Riili M, Giardina E, Dieli F, Triolo G: The level of soluble Granzyme $A$ is elevated in the plasma and in the $V \gamma 9 / \mathrm{V} \delta 2 \mathrm{~T}$ cell culture supernatants of patients with active Behcet's disease. Clin Exp Rheumatol 2004, 22(4 Suppl 34):S45-49.

doi:10.1186/ar4147

Cite this article as: Parlakgul et al:: Expression of regulatory receptors on $\gamma \delta$ T Cells and their cytokine production in Behcet's disease. Arthritis Research \& Therapy 2013 15:R15.

\section{Submit your next manuscript to BioMed Central and take full advantage of:}

- Convenient online submission

- Thorough peer review

- No space constraints or color figure charges

- Immediate publication on acceptance

- Inclusion in PubMed, CAS, Scopus and Google Scholar

- Research which is freely available for redistribution

Submit your manuscript at www.biomedcentral.com/submit 